\title{
MOLECULAR MARKERS
}

\author{
JUNE SIMPSON \\ Department of Genetic Engineering, CINVESTAV, Unidad Irapuato, \\ Apartado Postal 629, Irapuato, Guanajuato, México. \\ E-mail: jsimpson@irapuato.ira.cinvestav.mx
}

\begin{abstract}
Resumen. Los marcadores moleculares son una herramienta necesaria en muchos campos de la biología, incluyendo; bio-medicina, mejoramiento, ciencias forenses y estudios de diversidad. Además se utilizan para localizar y aislar genes de interés. Ya existe una gran variedad de técnicas para llevar a cabo análisis de marcadores moleculares basados en ADN. Las técnicas individuales involucran distintas metodologías usadas rutinariamente en la biología molecular. Los diferentes tipos de marcadores se distinguen por su capacidad de detectar polimorfismo en loci únicos o múltiples y si son de tipo dominante o co-dominante. El sistema óptimo de marcador molecular dependerá de la infraestructura de cada laboratorio y de las aplicaciones que son de interés para el investigador.

Palabras claves: marcadores moleculares, ADN, polimorfismo.

Abstract. Molecular markers are becoming essential tools in many areas of biology including bio-medicine, breeding, forensics and diversity analysis. In addition they are also being exploited to locate and isolate genes of interest. A variety of DNA based molecular marker techniques are now available. Individual techniques employ different methods used routinely in molecular biology and different kinds of markers are distinguished by their capacity to detect polymorphism at one or many loci and whether they are dominant or co-dominant markers. The choice of marker system will depend on individual laboratory facilities and the applications of interest to each researcher.
\end{abstract}

Key words: Molecular markers, DNA, polymorphism.

M ost of us are accustomed to classifying humans and other organisms based on genetic markers although we may not consciously recognize them as such. For example we easily distinguish between people with brown eyes or those with blue, we choose fruit based on size and color etc. For centuries farmers and later breeders have selected for desirable characteristics based on these kinds of morphological traits. Although this type of selection has proved extremely successful, many traits such as yield, disease resistance or stress tolerance are much more difficult to select for based on visual characteristics alone. In these cases selection is also complicated by environmental influences which mask the true genetic effects.

For many years investigators have attempted to develop new genetic markers mainly based on proteins or other molecules which can be used to discriminate between different individuals. Isozymes, were first developed in the 1950's (Markert, C.L. and Moller,
F. 1959). Small differences at the DNA level or during processing of the protein, can cause differences in the structure or charge of an enzyme without affecting its activity. However, these small changes can be detected as a differential migration following electrophoresis and staining for activity, normally in starch gels. Different bands on the gel relate to different alleles of the genes encoding the enzyme and are inherited in a Mendelian fashion. Since both alleles at a particular locus can be detected and heterozygotes easily identified, the isozyme system is codominant. Isozymes have been widely used in genetic mapping (Granger, A.R. 1996), in tagging genes of interest such as nematode resistance in tomato (Rick, C.M. and Fobes, J.F. 1974) and in studies of genetic diversity in plants (Perez de la vega, M. 1993).

Another type of protein marker which has been widely used is the analysis of different forms of storage proteins. For example the storage protein Phaseo- 
lin from the common bean, Phaseolus vulgaris has been used to compare bean germplasm from different regions of Latin America. Based on this data it was shown that two large gene pools for $P$. vulgaris exist, one in the Andean region the other in Meso-America (Gepts, P. et al. 1986).

Other compounds have also been used as molecular markers, such as phenolic compounds, anthocyanins, flavonoids and glycosides. However, the chromatographic techniques needed to analyze these molecules are often time-consuming and expensive, making them impractical for use with large populations (McKee, G.W. 1973).

In general the main problems associated with the use of biochemical markers are: low levels of polymorphism, the need to use specific tissues or specific developmental stages, the need for substantial amounts of tissue and the possible influence of environmental factors on the presence or absence of the compound or protein under analysis. In spite of these drawbacks, biochemical molecular markers and in particular protein type markers continue to be used successfully either on their own or in combination with DNA based markers.

The new generation of molecular markers are the DNA based markers. The concept of DNA based molecular markers was first developed by Botstein, et al. (1980) who proposed the use of restriction enzyme digests of genomic DNA for the detection of polymorphism. This idea is based on the fact that most natural populations have relatively high levels of phenotypically neutral polymorphisms, due to small changes in DNA sequence such as point mutations, base substitutions, insertions, deletions and translocations. In the case of the Restriction Fragment Length Polymorphisms (RFLP's) proposed by Botstein, any small mutation which affects a restriction enzyme site or the region close to the site will result in restriction fragments of different sizes in different individuals. By using a specific probe, these different sized fragments can be detected following Southern blotting and hybridization (Southern, E.M. 1975). As in the case of the isoenzymes, RFLP's are codominant markers.

The success of the Polymerase Chain Reaction (PCR) (Mullis, K.B. 1990) allowed the development of molecular markers based on this technique such as the Random Amplified Polymorphic DNA (RAPD) (Welsh, J. and McClelland, M. 1990; Williams, J.G.K. et al. 1990) method or DNA Amplified Fragment (DAF) (CaetanoAnolles, G. et al. 1991) technique and most recently the Amplified Fragment Length Polymorphism (AFLP) (Vos, P. et al. 1995) technique. The first two techniques are based on the use of short random oligonucleotides for initiation of the PCR amplification reactions. The presence or absence of amplified fragments in different individuals discriminates between these individuals. Polymorphism in the case if RAPD and DAF is due to mutations which affect regions at or close to the primer annealing sites. In most cases it is not possible to distinguish heterozygotes, therefore, these methods in genetic terms are dominant/recessive systems. The AFLP method is a combination of RFLP with PCR since in this case amplification reactions are carried out using primers specific for given restriction enzyme sites. Again, as in the case of RFLP's, the polymorphism observed is due to mutations at or close to restriction enzyme sites. Since the differences between individuals are based on presence or absence of a band, AFLP like RAPD is a dominant/recessive system although van Eck et.al. (1995) have proposed a method for determining and analyzing heterozygotes.

Molecular markers may be multi-locus or single locus markers. In the case of multi-locus markers many bands will be observed in a single analysis whereas for single locus systems, a maximum of two bands, one corresponding to each allele will be observed in a diploid genome. In the case of RFLP's for mapping purposes, single locus markers are normally used. However, certain multi-locus RFLP's, using probes for repeated sequences, have been developed. These markers are also often known as mini/micro satellites or Variable Number of Tandem Repeat (VNTR) markers (Beckmann, J.S. and Soller, M. 1990), in which the polymorphism and the size of fragment observed depends on the number of tandem repeats which are present in each region of the genome. RAPD, DAF and AFLP are all multi-locus markers.

Depending on the objectives of the study, investigators may choose to use either single locus or multilocus markers or a combination of both. In the case of population genetics studies, multilocus markers are most efficient since the purpose is to discriminate between individuals of a population based on the overall pattern of bands. Multilocus markers therefore quickly provide genome wide information on different individuals. For this reason they are the markers of choice for discrimination of individuals in legal matters (Gill, P. et al. 1985; Weir, B.S. 1995), for carrying out germplasm characterization (Hill, M. et al. 1996) and phylogenetic studies (Lin, J.-J. and Kuo, J. 1995).

The advantages of DNA based markers over other types of molecular markers are: the detection of high levels of polymorphism, the potentially unlimited number of markers, the lack of environmental or epistatic effects, DNA can be extracted from almost any part of the organism regardless of the developmen- 
tal stage and little tissue is needed to carry out the analysis.

Based on molecular marker systems, new strategies for genome analysis, gene cloning and breeding have been developed. The possibility to have markers very closely linked to traits of interest means that breeders can now use this information in their breeding programs, for example in the selection of disease resistant germplasm without the need to carryout extensive infections of the materials under evaluation. Methods have also been developed for the selection of complex traits such as yield or stress resistance. These strategies go under the general heading of Marker Assisted Selection or MAS (Paterson, A.H. et al. 1991; Tanksley, S.D. et al. 1989).

The development of molecular markers has led to an explosion in genome analysis in many organisms including plants. Until the mid 1980's few plants with the exception of maize and tomato had well developed genetic maps. Now most crop plants, many exotic species including perennials such as coffee (Paillard, M. et al. 1996) and even several tree species (Plomion, C. et al. 1995)) have genetic maps. Maps were originally developed with single locus RFLP markers but VNTR's, RAPD and AFLP are all now widely used.

MAS can be carried out without the development of a full scale genetic map, however saturated maps are essential for the dissection of complex traits and for map-based cloning strategies (Paterson, A.H. et al. 1988; Tanksley, S.D. 1993; Tanksley, S.D. et al. 1995). Using map-based cloning techniques, many genes known only by phenotype and pattern of genetic segregation have already been cloned such as the Pto gene for resistance to Pseudomonas syringae in tomato (Martin, G.B. et al. 1993). DNA based markers are also being widely used in projects for physical mapping for example of the Arabidopsis genome.

As mentioned above several molecular marker systems are available and all have their advantages and disadvantages. All of the DNA based techniques are expensive when compared with isozymes or morphological markers however, the amount of information obtained usually outweighs this factor. RAPD's and DAF's have been developed for use without radioactivity and are relatively cheap. These marker systems have been criticized for lack of reproducibility, but under controlled conditions within a laboratory can be very consistent and are being widely used. The RFLP system and the use of VNTR's involves a large amount of preliminary work to prepare probes from a genebank or in the case of VNTR's, the identification and cloning of repeated sequences. Both techniques can be made more efficient by incorporating PCR methods but this also implies sequencing of the clones and synthesis of oligonucleotides. Originally RFLP's were also radioactively base methods but now many groups have adopted non-radioactive labels such as chemiluminescent or fluorescent compounds. The AFLP technique also involves the use of radioactivity but fluorescent labels specific for AFLP's are also beginning to be used.

The integration of molecular marker methods is becoming essential for groups interested in genome analysis, phylogenetic analysis and germplasm characterization and there are now several options available as mentioned above. In the end the best marker system is the one which suits the objectives and infrastructure of each individual investigator or group.

\section{References.}

Beckmann, J.S., and Soller, M. 1990. Toward a unified approach to genetic mapping of eukaryotes based on sequence tagged microsatellite sites. Biotechnology 8:930-932.

Botstein, D., White, R.L., Skolnick, M., and Davis, R.W. 1980. Construction of a genetic linkage map in man using restriction fragment length polymorphisms. American Journal of Human Genetics 32:314-331.

Caetano-Anolles, G., B.J., B., and Gresshoff, P.M. 1991. DNA amplification fingerprinting using very short arbitrary oligonucleotide primers. Biotechnology 9:553-557.

Gepts, P., Osborn, T.C., Rashka, K., and Bliss, F.A. 1986. Phaseolin protein variability in wild forms and land races of the common bean (Phaseolus vulgaris): evidence for multiple centers of domestication. Economic Botany 40:451-468.

Gill, P., Jeffreyst, A.J., and Werrett, D.J. 1985. Forensic application of DNA "fingerprints". Nature 318:577-579.

Granger, A.R. 1996. Inheritance and linkage of isozymes in sweet cherry (Prunus avium L.). Teoretical and Applied Genetics 93:426-430.

Hill, M., Witsenboer, H., Zabeau, M., Vos, P., Kesseli, R., and Michelmore, R. 1996. PCR-based fingrprinting using AFLP's as a tool for studying genetic relationships in Lactuca spp. Theorical and Applied Genetics 93:1202-1210.

Lin, J.J., and Kuo, J. 1995. AFLP: A novel PCR-based technique for plant and bacterial DNA fingerprinting. Focus 17(2):66-70.

Markert, C.L., and Moller, F. 1959. Multiple forms of enzymes: tissue ontogenics, and species specific patterns. Proceedings of the National Academy of Science, USA 47:753-763.

Martin, G.B., Brommonschenkel, S., Chunwongse, J., Frary, A., Ganal, M., Spivey, R., Wu, T., Earle, E., and Tanksley, S.D. 1993. Map-based cloning of a protein kinase gene conferring disease resistance in tomato. Science 262:1432-1436.

McKee, G.W. 1973. Chemical and biochemical techniques for varietal identifications. Seed Science Technology 1:181199. 
Mullis, K.B. 1990. The unusual origin of the polymerase chain reaction. Scientific American 262:56-65.

Paillard, M., Lashermes, P., and Petiard, V. 1996. Construction of a molecular linkage map in coffee. Theorical and Applied Genetics 93:41-47.

Paterson, A.H., Lander, E.S., Hewitt, J.D., Paterson, S., S.E., L., and Tanksley, S.D. 1988. Resolution of quantitative traits into Mendelian factors by using a complete linkage map of restriction fragment length polymorphisms. Nature 335:721-726.

Paterson, A.H., Tanksley, S.D., and M., S. 1991. DNA markers in plant improvement. Advances in Agronomy 46:40-90.

Perez de la vega, M. 1993. Biochemical characterization of populations. En Plant breeding:Principles and prospects. Edited by M. D. Hayward, N. O. Bosemark and I. Romagosa. 184-200. London: Chapman and Hall.

Plomion, C., Bahrman, N., Durel, C.-E., and O'Malley, D.M. 1995. Genomic mapping in Pinus pinaster (Maritime pine) using RAPD nad protein markers. Heredity 74:661-668.

Rick, C.M., and Fobes, J.F. 1974. Association of an allozyme with nematode resistance. Report of the Tomato Genetics Cooperative 24:25.

Southern, E.M. 1975. Detection of specific sequences among DNA fragments separated by gel electrophoresis. Journal of Molecular Biology 98:503-517.

Tanksley, S.D. 1993. Mapping polygenes. Annual Review of Genetics 27:205-233.
Tanksley, S.D., Ganal, M.W., and Martin, G.B. 1995. Chromosome landing a paradigm for map-based cloning in plants with large genomes. Trends in Genetics 11(2):63-68.

Tanksley, S.D., Young, N.D., Paterson, A.H., and Bonierbale, M.W. 1989. RFLP mapping in plant breeding: new tools for an old science. Biotechnology 7:257-263.

van Eck, H., Rouppe van der Voort, J., Draaistra, J., van Zandvoort, P., van Enckevort, E., Segers, B., Peleman, J., Jacobsen, E., helder, J., and Bakker, J. 1995. The inheritance and chromosomal location of AFLP markers in a non-inbred potato offspring. Molecular Breeding 1:397410.

Vos, P., Hogers, R., Bleeker, M., Reijans, M., van de Lee, T., Hornes, M., Frijters, A., Pot, J., Peleman, J., Kuiper, M., and Zabeau, M. 1995. AFLP: A new technique for DNA fingerprinting. Nucleic Acids Res. 23:4407-4414.

Weir, B.S. 1995. DNA statistics in the SImpson matter. $\mathrm{Na}$ ture Genetics 11:365-368.

Welsh, J., and McClelland, M. 1990. Finger printing genomes using PCR with arbitrary primers. Nucleic Acids Research 18:7213-7218.

Williams, J.G.K., Kubelik, A.R., Livak, K.J., Rafalski, J.A., and Tingey, S.V. 1990. DNA polymorphisms amplified by arbitrary primers are useful as genetic markers. Nucleic Acids Research 18:6531-6535. 